\title{
Does median nerve translate pre- and postoperatively in carpal tunnel syndrome?
}

\author{
Karpal tünel sendromunda median sinir ameliyat öncesi ve sonrasında yer değiştirir mi?
}

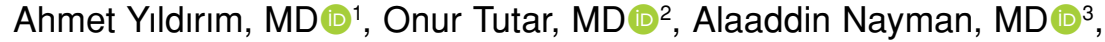 \\ Levent Yalçın, MD(iD), Egemen Altan, MD (D) 5 \\ 'Department of Orthopedics and Traumatology, Selçuk University Medical Faculty, Konya, Turkey \\ ${ }^{2}$ Department of Radiology, İstanbul University Cerrahpaşa Medical Faculty, İstanbul, Turkey \\ ${ }^{3}$ Department of Radiology, Selçuk University Medical Faculty, Konya, Turkey \\ ${ }^{4}$ Manus Hand Surgery Center, İstanbul, Turkey \\ ${ }^{5}$ Department of Orthopedics and Traumatology, Kadıkoy Florence Nightingale Hospital, İstanbul, Turkey
}

\begin{abstract}
Objectives: This study aims to evaluate the distance between the median nerve and the hook of the hamate pre- and postoperatively in patients with carpal tunnel syndrome and to investigate the efficiency of magnetic resonance imaging in diagnosis and postoperative follow-up.
\end{abstract}

Patients and methods: Median nerve decompression was performed by releasing the carpal tunnel in 15 patients (4 males, 11 females; mean age 51 years; range, 41 to 66 years) with carpal tunnel syndrome. The shortest distance between the median nerve and the hook of the hamate was measured with magnetic resonance imaging preoperatively and at three months after the operation and radial and ulnar translations were assessed. Findings were compared to those of a control group of 15 subjects (5 males, 10 females; mean age 52.2 years; range, 40 to 65 years).

Results: Median nerve shifted ulnarwards in patients with carpal tunnel syndrome. An intragroup evaluation of five patients with thenar atrophy revealed that as disease severity increased, the degree of the nerve's medial translation increased. Compared to preoperation, the median nerve significantly shifted to the radial side after decompression.

Conclusion: In carpal tunnel syndrome patients, we observed significant ulnar translation of the median nerve and lateral translation after releasing the carpal tunnel. Magnetic resonance imaging may be used to establish a diagnosis and to assess operation success in advanced carpal tunnel syndrome patients who may recover slowly postoperatively.

Keywords: Carpal tunnel syndrome; median nerve; operation; release; translation.

\section{öz}

Amaç: Bu çalışmada karpal tünel sendromlu hastalarda median sinir ve hamatum çengeli arasındaki mesafe ameliyat öncesi ve sonrasında değerlendirildi ve manyetik rezonans görüntülemenin tanı ve ameliyat sonrası takipte etkinliği araştırıldı.

Hastalar ve yöntemler: Karpal tünel sendromlu 15 hastada (4 erkek, 11 kadın; ort. yaş 51 yıl; dağılım, 41-66 yıl) karpal tünel gevşetilerek median sinir dekompresyonu uyguland. Median sinir ile hamatum çengeli arasındaki en kısa mesafe ameliyat öncesinde ve ameliyattan üç ay sonra manyetik rezonans görüntüleme ile ölçülerek radial ve ulnar yer değiştirme değerlendirildi. Bulgular 15 denek (5 erkek, 10 kadın; ort. yaş 52.2 yıl; dağılım, 40-65 yıl) içeren kontrol grubununkiler ile karşılaştırıldı.

Bulgular: Karpal tünel sendromlu hastalarda median sinir ulnar tarafa kaydı. Tenar atrofisi olan beş hastanın grup içinde değerlendirilmesiyle hastalık şiddeti arttıkça sinirin mediale yer değiştirme derecesinin de arttığı görüldü. Ameliyat öncesine göre, dekompresyon sonrası median sinir belirgin olarak radial tarafa kayd.

Sonuç: Karpal tünel sendromlu hastalarda median sinirde belirgin ulnar yer değiştirme ve karpal tünel gevşetilmesi sonrası lateral yer değiştirme gözlemlendi. Manyetik rezonans görüntüleme ameliyat sonrası geç iyileşebilecek ileri evre karpal tünel sendromlu hastalarda tanı koymak ve ameliyat başarısını değerlendirmek için kullanılabilir.

Anahtar sözcükler: Karpal tünel sendromu; median sinir; ameliyat; gevşetme; yer değiştirme. 
Carpal tunnel syndrome (CTS) is the most common compressive neuropathy in the upper extremity. It is caused by increased pressure or pressure-induced injury on the median nerve in its course through the carpal tunnel ${ }^{[1]}$ It is clear that the size and shape of the median nerve are highly affected by the increased pressure and several morphological changes have been shown in previous studies. ${ }^{[2]}$ Moreover, release of the transverse carpal ligament (TCL) can improve the clinical condition of patients with CTS and reduce the pressure in the carpal tunnel.

Several studies have used magnetic resonance imaging (MRI) for the assessment of CTS and have described characteristic MRI findings in CTS patients. ${ }^{[1-3]}$ These findings include lesions with high signal intensity on $\mathrm{T}_{2}$-weighted images, swelling of the nerve in the proximal and distal carpal tunnel and flattening of the median nerve within the carpal tunnel. However, to the best of our knowledge, the relative position of the median nerve has not been studied in the literature, nor the effect of carpal tunnel release (CTR) on its location within the carpal tunnel. ${ }^{[4]}$ Therefore, in this study, we aimed to evaluate the distance between the median nerve and the hook of the hamate pre- and postoperatively in patients with CTS and to investigate the efficiency of MRI in diagnosis and postoperative follow-up.

\section{PATIENTS AND METHODS}

The study was conducted at Selçuk University Medical Faculty between July 2015 and July 2017 and included 15 patients (4 males, 11 females; mean age 51 years; range, 41 to 66 years) with idiopathic CTS. The primary criteria for inclusion were failure of conservative management of CTS, and mini open CTR was performed on all patients with complete resolution of symptoms (numbness, tingling and pain). The diagnosis of CTS was based on a history and physical examination including Tinel's sign and Phalen's maneuver consistent with compression of the median nerve at the wrist. Additionally, electrophysiological studies were performed preoperatively in all cases to confirm the diagnosis. All patients had Body Mass Indexes between 18 and 29 to avoid any negative effect of hypertrophic adipose tissue. The exclusion criteria were patients who had any previous hand trauma; surgery; any comorbidities as cervical disc diseases, thoracic outlet syndrome, carpal arthritis, previous injections to the operation side as corticosteroids or local anesthetics, ongoing pain or numbness for three months postoperatively or any space-occupying lesion in the carpal tunnel verified with MRI. The study protocol was approved by the Selçuk University Medical Faculty Ethics Committee. A written informed consent was obtained from each patient. The study was conducted in accordance with the principles of the Declaration of Helsinki.

The mini open CTR was performed with use of general anesthesia by the same surgeon with six-year experience. The incision began $2 \mathrm{~mm}$ ulnar to the thenar crease, just distal to the Kaplan oblique line and extended 1.5 to $3 \mathrm{~cm}$ proximally to the distal crease of the wrist. The superficial palmar fascia, transverse carpal ligament, and antebrachial fascia were selectively seen, and the contents of the carpal tunnel were inspected. Neither tenosynovectomy nor neurolysis was performed. The tourniquet was deflated and satisfactory hemostasis was obtained.

Magnetic resonance imaging was performed preoperatively and at three months after the operation to assess localization changes of the median nerve in the carpal tunnel. The comparison of pre- and postoperative images was made at the level of the hook of the hamate. Magnetic resonance imaging examinations were performed with 1.5 Tesla MR scanner (Avanto; Siemens, Erlangen, Germany) with dedicated eight-channel wrist coil and the arm in an overhead, elbow-extended, wrist-pronated position. Magnetic resonance images were obtained with the following parameters: a coronal T1-weighted sequence (repetition time milliseconds $[\mathrm{msec}] / \mathrm{ECHO}$ time msec: 420/11), a coronal short tau inversion recovery sequence (repetition time $\mathrm{msec} / \mathrm{ECHO}$ time msec: 3310/48, inversion time: $150 \mathrm{msec}$ ), an axial intermediate-weighted fat-suppressed fast spin-ECHO sequence (repetition time $\mathrm{msec} / \mathrm{ECHO}$ time msec: 2600/35), an axial $\mathrm{T}_{1}$-weighted sequence (repetition time msec/ECHO time msec: 420/11). A $11 \times 10-\mathrm{cm}$ field of view and 3-mm-thick sections with no intersection gap were used.

Pre- and postoperatively, the shortest distances between the median nerve and the hook of the hamate, which is reported to be a constant bony landmark, ${ }^{[4]}$ were measured on transverse plane images (Figure 1). Measurements were performed by two experienced musculoskeletal radiologists, who were blind to the patient and control groups, on the axial and coronal MR images.

A control group of 15 patients ( 5 males, 10 females; mean age 52.2 years; range, 40 to 65 years) was established to compare the localization changes between the groups. The control subjects were selected from normal individuals who had no prior hand surgery, trauma and had no clinical findings of CTS. They were matched similar to the CTS patients for age, gender and weight. 

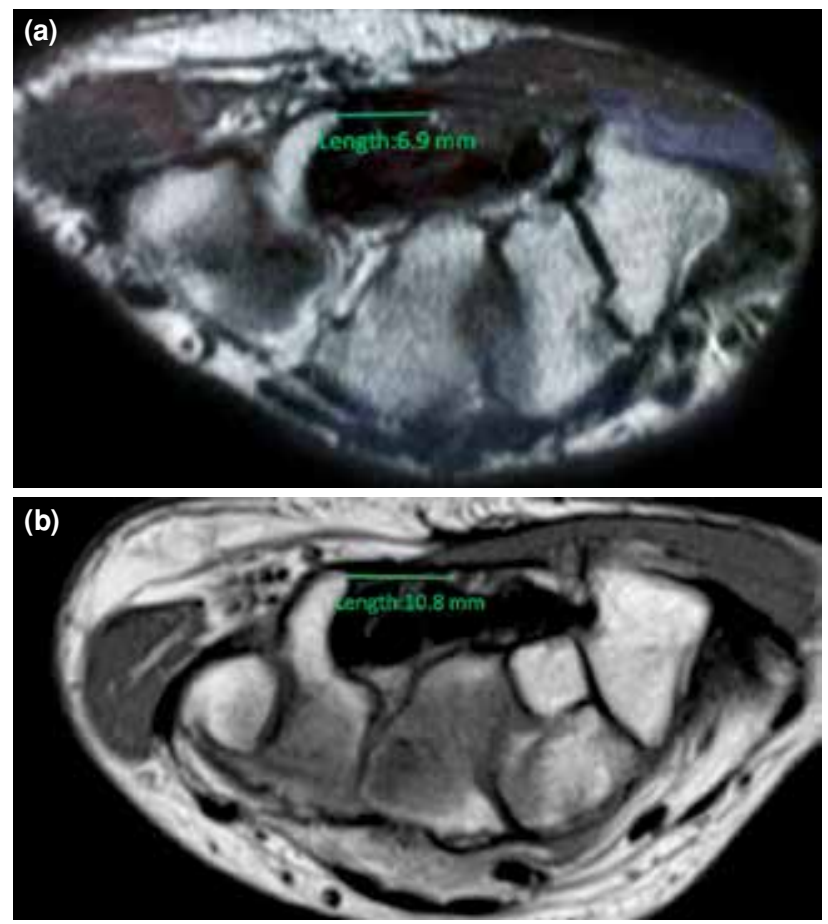

Figure 1. (a) Preoperative shortest distance between median nerve and hook of hamate in carpal tunnel. (b) After surgical release, significant radial translation of median nerve.

\section{Statistical analysis}

Statistical analyses were performed using the IBM SPSS version 21.0 software (IBM Corp., Armonk, NY, USA). The Kolmogorov-Smirnov test was used to analyze the normal distribution of data. The shortest distance of median nerve relative to hook of hamate was studied by Mann-Whitney U test between patients with CTS and controls. Also, the Wilcoxon test was used for pre- and postoperative shortest distance of median nerve relative to hook of hamate in patients who underwent surgery. Statistical significance was accepted at a $p$ value of less than 0.05 .

\section{RESULTS}

The age and gender distribution of the control group was not significantly different from the patient group ( $\mathrm{p}=0.27)$ The patients presented mainly with symptoms of pain, numbness and tingling. The preoperative diagnosis of CTS was also confirmed with electromyography (EMG) studies for all patients.

According to MRI measurements, the preoperative mean distance of the median nerve to the hook of the hamate was $8.6 \mathrm{~mm}$ in patients and $11.05 \mathrm{~mm}$ in the control group. When compared with the control group, this represented a significant ulnar shift
TABLE I

Measurement of distances between median nerve and hook of hamate pre- and postoperatively and in control group

\begin{tabular}{lcc}
\hline & Mean \pm SD & Min-Max \\
\hline Preoperatively $(\mathrm{mm})$ & $8.62 \pm 2.156$ & $4.30-11.00$ \\
Postoperatively $(\mathrm{mm})$ & $10.00 \pm 1.462$ & $7.40-12.20$ \\
Control group $(\mathrm{mm})$ & $11.05 \pm 195$ & $9.70-13-80$ \\
\hline
\end{tabular}

SD: Standard deviation; Min: Minimum; Max: Maximum.

of the median nerve $(\mathrm{p}<0.05)$ in CTS patients. At three months postoperatively, MRI demonstrated a significant shift to the radial side when compared to the preoperative location $(p<0.05)$. At that time period, the mean distance from the median nerve to the hook of hamate was also measured as $10.0 \mathrm{~mm}$ (Table I). Moreover, the distance between the median nerve and the hook of hamate did not show any significant difference between the control group and the patients at three months postoperatively $(\mathrm{p}=0.12)$.

An assessment of a subgroup of patients $(n=5)$ with thenar atrophy revealed that the mean distance of the median nerve to the hook of the hamate was $6.1 \mathrm{~mm}$. These nerves demonstrated significantly more ulnar shift when compared with patients who did not have thenar atrophy $(\mathrm{p}<0.05)$.

\section{DISCUSSION}

In our study, we attempted to define the changes of median nerve localization before and after CTR. The present study showed that the median nerve presentation in the carpal tunnel was significantly different than those in asymptomatic volunteers, providing evidence that increased ulnar side orientation on coronal plane of median nerve might be a sign of CTS and a reliable imaging finding in the evaluation of CTS.

Despite the fact that EMG is the best diagnostic method if clinical and/or provocative tests are positive and surgical management is being considered for primary CTS, there is still controversy in the literature concerning the correlation between EMG results and the outcome of surgical decompression of the median nerve. ${ }^{[5]}$ There are many reports demonstrating positive or negative correlation between EMG results and clinical findings. ${ }^{[5-9]}$ Magnetic resonance imaging can be particularly helpful for patients who did not benefit from surgery or for recurrence cases. Since our study demonstrated that the postoperative localization of the median nerve is statistically close 
to normal individuals, we might expect an abnormal localization for the recurrence cases and MRI may be a good choice and predictor for recurrent or refractory cases. Likewise, Campagna et al. ${ }^{[10]}$ suggested the use of MRI for accurate postoperative evaluation of CTS patients.

Our study showed that the median nerve shifted ulnarwards in CTS patients when compared with the control group. This is most likely the result of the increased pressure in the carpal tunnel and these findings might be helpful for understanding the biomechanics of CTS. Also, Jones et al. ${ }^{[11]}$ proposed that a number of patients might have persistent symptoms after CTS and develop recurrent symptoms caused by circumferential fibrosis. This kind of fibrosis may lead to an excessive ulnarwards shift of the median nerve and can be monitored with the use of MRI for advanced or recurrent cases. Additionally, our study evaluated the MRI findings after release of the TCL. When we compared with the preoperative location, we observed that the median nerve shifted to the radial side with a significant degree. Our finding was attributed to the reduced pressure. Carpal tunnel syndrome affects $1 \%$ of the general population and $5 \%$ of the working population. Therefore, CTR is one of the most common procedures performed on the hand.$^{[1,2]}$ Magnetic resonance imaging is a sensitive method to diagnose CTS; and traditionally, signal changes were used for diagnosis of CTS. ${ }^{[3,4]}$ Since the appearance of the first MRI reports of the median nerve in the carpal tunnel in the early 1990s, MRI has been recently shown to be of potential value in the diagnosis of CTS through achieved high-resolution imaging by using small surface coils and a limited field of view. Additionally, many imaging studies have demonstrated the ability of MRI to accurately assess the morphological aspects of CTS. In these studies, enlargement and flattening of the median nerve, as well as palmar displacement after TCL release, have been reported. ${ }^{[2,4,12]}$ The distance between the median nerve and the flexor pollicis longus tendon was significantly greater in CTS patients than in healthy volunteers during thumb motion. ${ }^{[13-15]}$ However, most musculoskeletal radiologists interpret a signal change in the peripheral nerve only as an increase or no increase by visual inspection, which may lead to interpretation errors. So, the signal changes of the different MRI planes may be subjective criteria to determine the signs of CTS; even in the presence of obvious signal changes on MRI, it can be challenging for radiologists to describe the extent of the increased signal intensity in the median nerve. Thus, the measurement of a distance between the median nerve and a constant point at a specific MRI plane may be an easy, reproducible and objective criterion.

The present study has some limitations. Some patients with possible subclinical CTS may have been included in the control group, which consisted mainly of middle-aged subjects. However, all volunteers underwent screening using a survey and physical examination to avoid misclassifying CTS patients as control subjects.

In conclusion, unlike previous MRI studies, our results indicate that MRI can detect nerve position changes according to a reference point like the hook of hamate. Our study also shows that tunnel release causes significant localization changes postoperatively when compared with preoperative images. At early postoperative stage, physical examination and other diagnostic methods as ultrasonography and electrophysiological studies may not be beneficent for patients with persistent symptoms because of nerve edema or electrodiagnostic abnormalities. Thus, pre- and postoperative MRI may be used to investigate and even monitor CTS patients quantitatively.

\section{Declaration of conflicting interests}

The authors declared no conflicts of interest with respect to the authorship and/or publication of this article.

\section{Funding}

The authors received no financial support for the research and/or authorship of this article.

\section{REFERENCES}

1. Ulusoy EK, Çıraklı A, Ekinci Y. The effect of metabolic syndrome on recurrence in patients who had undergone surgery for carpal tunnel syndrome. Eklem Hastalik Cerrahisi 2017;28:158-63.

2. Kim S, Choi JY, Huh YM, Song HT, Lee SA, Kim SM, et al. Role of magnetic resonance imaging in entrapment and compressive neuropathy--what, where, and how to see the peripheral nerves on the musculoskeletal magnetic resonance image: part 2. Upper extremity. Eur Radiol 2007;17:509-22.

3. Bulut T, Sener U, Yağdi S, Kazimoğlu C, Sener M. Relationship between clinical and electrophysiological results in surgically treated carpal tunnel syndrome. Eklem Hastalik Cerrahisi 2011;22:140-4.

4. Beck JD, Jones RB, Malone WJ, Heimbach JL, Ebbitt T, Klena JC. Magnetic resonance imaging after endoscopic carpal tunnel release. J Hand Surg Am 2013;38:331-5.

5. Ağırman M, Kara A, Durmuş O, Saral İ, Çakar E. Isokinetic evaluation of wrist muscle strength in patients of carpal tunnel syndrome. Eklem Hastalik Cerrahisi 2017;28:41-5.

6. Dhong ES, Han SK, Lee BI, Kim WK. Correlation of electrodiagnostic findings with subjective symptoms in carpal tunnel syndrome. Ann Plast Surg 2000;45:127-31.

7. Schrijver HM, Gerritsen AA, Strijers RL, Uitdehaag BM, Scholten RJ, de Vet HC, et al. Correlating nerve conduction 
studies and clinical outcome measures on carpal tunnel syndrome: lessons from a randomized controlled trial. J Clin Neurophysiol 2005;22:216-21.

8. Choi SJ, Ahn DS. Correlation of clinical history and electrodiagnostic abnormalities with outcome after surgery for carpal tunnel syndrome. Plast Reconstr Surg 1998;102:2374-80.

9. Kanatani T, Fujioka H, Kurosaka M, Nagura I, Sumi M. Delayed electrophysiological recovery after carpal tunnel release for advanced carpal tunnel syndrome: a two-year follow-up study. J Clin Neurophysiol 2013;30:95-7.

10. Campagna R, Pessis E, Feydy A, Guerini H, Le Viet D, Corlobé $\mathrm{P}$, et al. MRI assessment of recurrent carpal tunnel syndrome after open surgical release of the median nerve. AJR Am J Roentgenol 2009;193:644-50.

11. Jones NF, Ahn HC, Eo S. Revision surgery for persistent and recurrent carpal tunnel syndrome and for failed carpal tunnel release. Plast Reconstr Surg 2012;129:683-92.
12. Richman JA, Gelberman RH, Rydevik BL, Hajek PC, Braun RM, Gylys-Morin VM, et al. Carpal tunnel syndrome: morphologic changes after release of the transverse carpal ligament. J Hand Surg Am 1989;14:852-7.

13. Yoshii Y, Villarraga HR, Henderson J, Zhao C, An KN, Amadio PC. Ultrasound assessment of the displacement and deformation of the median nerve in the human carpal tunnel with active finger motion. J Bone Joint Surg Am 2009;91:2922-30.

14. Yoshii Y, Ishii T, Sakai S. Median nerve deformation during finger motion in carpal tunnel syndrome: correlation between nerve conduction and ultrasonographic indices. Hand Surg 2013;18:203-8.

15. van Doesburg MH, Henderson J, Mink van der Molen AB, An KN, Amadio PC. Transverse plane tendon and median nerve motion in the carpal tunnel: ultrasound comparison of carpal tunnel syndrome patients and healthy volunteers. PLoS One 2012;7:e37081. 